\title{
ELEMENTS OF CONTROL THEORY APPLIED TO AN INVESTMENT PORTFOLIO IN THE CAPITAL MARKET. THE OPTIMAL TIME HORIZON FOR SELLING A PORTFOLIO
}

\begin{abstract}
The article presents a concept of capital management for assembling investment portfolios. Two optimization variants of a portfolio to be purchased are discussed. Portfolio I is structural, using the „traditional model”. To assemble Portfolio II, elements of reliability theory and the dynamic programming method were used. The article also analyses the sale of a portfolio with respect to the demand for financial instruments in the capital market. The presented concept dealing with rational investment decisions during transactions at the Warsaw Stock Exchange can also be used by managers to create an effective portfolio of financial instruments.
\end{abstract}

Key words: control, optimal time, sale of portfolio.

\section{INTRODUCTION}

In optimising an investment portfolio in the capital market, not only is the future rate of return is important, but also the effectiveness of the invested capital. The latter criterion can be used to select an optimal portfolio.

\section{CONTROL PROCESSES}

To develop a sound and effective investment strategy for the capital market, the investor must be aware of various decision-making methods that allow maximisation of profits from the projected investment.

Let us assume that an investor has an $S$ amount of capital at time $t(S(t))$, which decreases with successive purchases of portfolios in the capital market. Hence [Pońsko 2000: 37]:

\footnotetext{
${ }^{*}$ Ph.D., Professor at the Higher School of National Economy in Kutno.
} 


$$
\frac{d S(t)}{d t}=-E(t)
$$

where:

$E(t)$ - the rate of capital depletion.

Let us now take investor's utility function $U(E)$, the value of which depends on the amount of capital $S(t)$ consumed. This function is controlled by variable $E(t)$, because the investor can freely set the rate of capital depletion and $E(t)$ has an obvious effect on the amount of $S(t)$. The problem of portfolio optimisation can be presented as follows:

$$
\max \int_{0}^{T} U(E) e^{-R t} d t, \text { for } E(t)=\frac{d S(t)}{d t},
$$

where:

$S(t)$ - the amount of capital,

$R \quad$ - the rate of return on the purchased portfolio,

$S(0)=S_{0}\left(S_{0}-\right.$ the initial amount of capital $)$,

$T \quad$ - the period under investigation.

\section{Example}

The amount of capital available to the investor is given by a trend function:

$$
S(t)=\alpha_{0}+\alpha_{1} t-\alpha_{2} t^{2}
$$

(hence, $\left.\frac{d S(t)}{d t}=\alpha_{1}-2 \alpha_{1} t=-E(t)\right)$.

Assuming that the function estimated with historical data is the following:

$$
S(t)=400+40 t-40 t^{2}
$$

we have: $S(0)=S_{0}=400, U(E)=\left[S_{0}-E(t)\right]$ - the initial capital decreased according to the rate of depletion. By integrating function $U(E)$ in conformity with the model of continuous capitalisation, the following present value of utility flow is obtained: 


$$
\int_{0}^{T} U(E) e^{-R t} d t
$$

where:

$R \quad$ - the rate of return on the purchased portfolio.

Let us optimise the portfolio using a modified approach. For control parameters $R=10 \%, T=10, R=10 \%$ and $T=10$ periods, the maximal present value of utility flow is the following:

$$
\max \int_{0}^{T} U(E) e^{-R t} d t
$$

where:

$U(E)$ - the value of capital consumed by market transactions. For $t=0$ (i.e. the time when transactions are made), the value of $U(E)$ is $U(0)=400-0=400$. Hence relationship (5) should be interpreted as the effectiveness of capital invested in the market over time $T$.

In simple terms, the maximisation procedure comes down to calculating the integer:

$$
\int_{0}^{10} 400 e^{-R t} d t=400 \int_{0}^{10} e^{-R t} d t=\left.\frac{-400}{R} e^{-R t}\right|_{0} ^{10}=\frac{-400}{R}\left(e^{-10 R}-1\right)=\frac{400}{R}\left(1-e^{-10 R}\right) .
$$

Under the assumed parameter values $(R=10 \%, T=10$ periods $)$, the present value $K$ of a continuous flow of income (utility) is:

$$
K=\frac{400}{0,1}\left(1-e^{-0,1 \cdot 10}\right)=4000 \cdot(1-0,3679)=2528,4 \text { units. }
$$

In optimising an investment portfolio, not only must the rate of return on the optimised portfolio be taken into account, but also the effectiveness of the invested capital. The latter criterion is also instrumental in choosing the optimal portfolio.

To understand the nature of the criterion, one must be aware of the occurrence of the conditional maximum problem, because the value of $\int_{0}^{T} U(E) e^{-R t} d t$ depends on $R^{\otimes}$, the amount of which represents the rate of return 
on the optimised portfolio (assuming that the rate can be determined for maximised income or minimised risk at the expected rate of return). When the investor chooses an alternative optimal portfolio or when a different expected optimal rate of return $(R)$ varying the present value of utility flow depending on $T$ is taken, the amount of investor's capital also changes (increasing or decreasing); the rate of capital depletion $E(t)$ is also likely to change over time. The initial amount of capital and time $T$ are precisely set by the investor, which reduces the range of possible solutions and limits control over the portfolio optimisation process ${ }^{1}$.

Let us evaluate the effectiveness of capital invested in two alternative optimal portfolios, which have been created using stock prices and rates of return yielded by selected companies (specific values are provided in the annexe).

Portfolio I created using ,a conventional” approach [Jajuga i Jajuga 1998], contains the stocks of four companies (PKM, GTC, RPC and WWL) in the following proportions:

$$
-1.336 \mathrm{PKM}+1.714 \mathrm{GTC}+0.673 \mathrm{RPC}-0.052 \mathrm{WWL} .
$$

By substituting the 11-month averages of the stocks' prices into the formula (see Table 1 in annexe), the following value of the portfolio at purchase (at $T=0$ ) is obtained:

$$
-1.336 \cdot 124.2+1.714 \cdot 166.3+0.673 \cdot 22.0-0.052 \cdot 155.5=125.8
$$

In evaluating the effectiveness of the invested capital, the possibility of short selling should be taken into account. If the cost of the transaction was 1.7 units, the investor would spend 124.1 units from their own resources.

Portfolio II [Tymiński i Zawiślak 2008] consists of the stocks of three companies (GTC, RPC and WWL) in the following proportions: $0.9 ; 0.1 ; 0.0$. Hence

$$
0.9 \mathrm{GTC}+166.3 \mathrm{RPC}+0.0 \mathrm{WWL}
$$

In this case, the investor will spend:

$$
0.9 \cdot 166.3+0.1 \cdot 23.0=151.9
$$

\footnotetext{
${ }^{1}$ A state variable is an argument of the objective function (i.e. a time function). A state can be changed only indirectly (see Pońsko [2000: 36]). In the presented analysis, the state variable is the amount of capital used to purchase a portfolio and the control variable is the rate of return on the optimized portfolio.
} 
For the first portfolio $R_{t}=15 \%$ and for the second portfolio $R_{I I}=9.57 \%$ [Tymiński i Zawiślak 2008]. According to the proposed concept, the amount of capital increase in the respective optimised portfolios is the following:

Portfolio I: $\int_{0}^{10} 124,1 e^{-0,15 t} d t=642,8$ units,
Portfolio II: $\int_{0}^{10} 151,9 e^{-0,0958 t} d t=978,5$ units.

The results of the evaluation allow a more profitable portfolio to be selected. They point out that portfolio II should be preferred because of the higher productivity of capital allocated to its purchase. The objective function is a model of continuous capitalisation that shows the present value of income flow. The model can easily be modified by replacing the exponential function $f(t)=e^{-R t}$ with a logarithmic function, a power (radical) or square function, etc., in accordance with the investor's utility function. In this case, the procedure proposed for assessing whether the choice of an optimal portfolio was right may also be used to establish how practical a projected type of investment is (bank deposits, real estate, a factory, etc.).

To ensure that investment decisions in the capital market are optimal, the best time for selling a portfolio must also be estimated.

\section{THE OPTIMAL TIME FOR SELLING A PORTFOLIO $-T^{\otimes}$}

One aspect of the decision-making process may be the sale of a stock portfolio in the capital market. To this end, the optimal sale time $t^{\otimes}$ must be determined, i.e. the most advantageous moment for maximising income represented by net present value $(N(t))$. Let the time-varying market value of the portfolio be denoted as $W(t)$ and the present value as $W(t) e^{-R t}$, where $W(t)$ stands for a specific amount of income (utility) for time $t$.

In estimating the portfolio value, investors must consider whether waiting for the optimal sale time $\left(t^{\otimes}\right)$ will not deprive them of profits because of the unavailability of other sources of income such as bank deposits. The investor could earn an alternative income $s$, if the amount of $\mathrm{W}$ could be invested in periods $t$. Therefore, the opportunity cost given by rate $k$ stands for a rate of return on alternative investments and it is a constant flow, the rate of which is $\mathrm{ke}^{\mathrm{a}}$ ( $a=R-s$ is a constant parameter that does not depend on time but only on the rate of return $R$ ). Then the total present value of opportunity costs over $T$ periods is: 


$$
K(t)=\int_{0}^{T} k e^{a} e^{-R t} d t
$$

A single amount of capital spent to purchase a portfolio can be considered to represent the opportunity cost of an alternative investment (e.g. a bank deposit). It can also be assumed that the amount spent on the portfolio is an alternative cost (A). Hence the optimisation model:

$$
\max N(t)=\max _{t}\left\{W(t) e^{-R t}-\int_{0}^{t} k e^{a} e^{-R t} d t-A\right\}
$$

To find a portfolio maximising the present net value, the extreme of function $N(t)$ must be calculated. Therefore:

$$
\max N(t)=\max _{t^{\otimes}}\left\{\left[W(t)+\frac{k e^{a}}{R}\right] e^{-R t}-\frac{k e^{a}}{R}-A\right\}
$$

In maximising $N(t)$ we need to find such a value of $t^{\otimes}$ that:

1) the derivative $\frac{d N(t)}{d t}$ equals zero (a necessary condition for the extreme to occur); in other words, the following equality must take place:

$$
W^{\prime}\left(t^{\otimes}\right)=R W\left(t^{\otimes}\right)+k e^{a}
$$

where $e^{-R t}$ always takes a positive value.

2) $N^{\prime \prime}\left(t^{\otimes}\right)<0$ (a sufficient condition for the maximum to occur), which is equivalent to the following inequality:

$$
W^{\prime \prime}\left(t^{\otimes}\right)-2 R W^{\prime}\left(t^{\otimes}\right)+R^{2} W\left(t^{\otimes}\right)+R k e^{a}<0
$$

The potential sale value of the portfolio may also be expressed as:

$$
W\left(t^{\otimes}\right)=k e^{b R t}
$$

where $k e^{b R t}$ denotes a greater opportunity cost of capital committed to the portfolio. According to (10), $W(t)$ depends on the rate of return $R$, time $t$ and a positive constant $b$ that represents change in the portfolio's rate of return at $t=0,1,2, . ., T$. Let us notice that for $t=0$ we have $N(0)=0$ (because $W(0)=A$, see formula (7)). This means that the sale value of a portfolio (i.e. return) is equal to the amount of the initial investment. 
Another aspect that an investor planning the sale of their portfolio needs to take into account is the market situation. The best time for selling a portfolio is when the transaction is likely to bring maximum profits. To estimate the amount of maximum profits that could be realised by selling stocks at the optimum time, function (10) should be substituted into formula (9). After transformation, we have:

$$
k e^{b R t} \cdot b R=k b R e^{b R t}+k e^{a}
$$

or

$$
t^{\otimes}=\frac{1}{b R}(a-\ln R(b-1) \text { for } b>1
$$

\section{Example}

Let us consider our problem with two optimised portfolios (I and II). In both cases the alternative investment is bank deposits. Let us assume that the long-term interest $s$ on the deposits is $6 \%$.

$R$ is $15 \%$ and $9.57 \%$ for portfolio I and II respectively. For both portfolios the values of parameters $a$ and $b$ must be calculated. Parameter $a$ is derived from formula $a=R-s$. so $a_{I}=0,09$ and $a_{I I}=0,0358$.

Parameter $b$ is a measure of variations in the portfolio effectiveness understood as a pace of change in the rate of return $\gamma_{F(R)}$ (or, in algebraic terms, in the rate of relative change in the cumulative distribution function $f(R)$ with respect to $F(R)$ ).

As regards portfolio I, stocks of companies PKM and WWL should be omitted from further analysis, given that they were obtained for short sale.

The trend in the value of $F(R)$ is identified by carrying out extrapolation with polynomials of order 3 . The values of $b$ are derived according to the proportions of stocks of the companies used in the analysis.

The $F(R)$ function for GTC and RPC stocks is respectively (see Table 2 in annexe):

$$
\begin{gathered}
F(R)_{G T C}=0,21850+0,027328 R+0,000516 R^{2}-0,0000182 R^{3}, \\
F(R)_{R P C}=0,329938+0,0467756 R+0,000623 R^{3} .
\end{gathered}
$$

For portfolio I (optimised in the traditional manner), a rate of change in the cumulative distributive function is calculated:

$$
\gamma_{F(R)_{G T C}}=\frac{f(R)}{F(R)}=0,137\left(R_{\mathrm{GTC}}=10.07 \%\right),
$$


for

$$
\gamma_{F(R)_{R P C}}=0.147\left(R_{P R C}=5.16 \%\right) .
$$

Considering the structure of stocks in portfolio I, we obtain:

$$
\gamma_{F(R) I(\text { porffel })}=0.127 \cdot 1.714+0.147 \cdot 0.673=0.3166\left(=b_{I}^{\prime \prime}\right) .
$$

For portfolio II (optimised using the bi-criteria modelling approach), we have:

$$
\gamma_{F(R) I I(\text { porffel })}=0,127 \cdot 0,9+0,147 \cdot 0,1=0,129\left(=b_{I I}^{\prime \prime}\right) .
$$

Let us notice that $b$ depends on three factors: $\gamma_{F(R)}$, the structure of the portfolio and time $(t)$. Hence $b=b^{\prime} \rtimes$. After transformation, formula (11) can be written as:

$$
k e^{b^{\prime} R t^{2}} R\left(b^{\prime} t-1\right)=k e^{a} .
$$

By substituting specific values into formula (12), we obtain:

$$
124.1 e^{0,3166 \cdot 0,15 t^{2}} \cdot 0.15\left(0.3166 t^{\otimes}-1\right)=124.1 e^{0,009} .
$$

By solving this equation, we arrive at the optimum time for selling the portfolio 1: $t_{I}^{\otimes}=6.4$ (months).

For portfolio II, we have:

$$
151.9 e^{0,129 \cdot 0,0958 t^{2 \otimes}} \cdot 0.0958\left(0,129 t^{\otimes}-1\right)=151.9 e^{0,0358} .
$$

In this case, the optimum selling time horizon is $t_{I I}^{\otimes}=14.4$ months.

The value of $t^{\otimes}$ arises from the particular market situation determined by the values of $R, b$ and $a$. It is noteworthy that $a=$ zero is a boundary on the positive effectiveness of capital $k$ and a negative value of $a$ points in the presented model to a declining market value of capital. In this case, the investor should opt for another investment, e.g. a bank deposit.

\section{SUMMATION AND CONCLUSIONS}

Under the assumed criterion $\max \left\{N\left(t^{\otimes}\right)\right\}$, portfolio II is more profitable in a longer term. Two factors play a decisive role: the rate of return $(R)$ and the measure of changes in portfolio effectiveness $(b)$. The faster their values 
grow, the shorter the optimal time horizon in which the portfolio can be sold (i.e. the investor needs less time to achieve a return on the investment).

However, a shorter period after which the portfolio is sold carries a greater risk that the transaction will be less profitable.

The presented analysis corroborates a general rule that higher profits involve greater risks. It must be stressed, however, that profits from reinvestments that the investor might realize by having the invested capital back after a shorter time have been omitted from the analysis, likewise the effectiveness of short sale in portfolio I.

\section{REFERENCES}

Bellman R., 1965, Adaptacyjne procesy sterowania, Wydawnictwo Naukowe PWN, Warszawa.

DeBondt W. F. M., Thaler R., 1960, Does the Stock Market Overreact, Journal Finance.

Chiang A. C., 1994, Podstawy ekonomii matematycznej, PWE, Warszawa.

Haugen R. A., 2000, Teoria nowoczesnego inwestowania, Wydawnictwo WIG PRESS, Warszawa. Jajuga K., Jajuga T., 1998, Inwestycje instrumenty finansowe, ryzyko finansowe, inżynieria finansowa, Wydawnictwo Naukowe PWN, Warszawa.

Pońsko P., 2000, Optymalizacja dynamiczna wzrostu gospodarczego, Wydawnictwo ELIPSA, Warszawa.

Trzaskalik T. (red.), 2004, Modelowanie preferencji a ryzyko, Wydawnictwo Akademii Ekonomicznej w Katowicach, Katowice.

Tymiński J., Zawiślak R., 2008, Dwukryterialna koncepcja wyboru instrumentów finansowych dla efektywnej konstrukcji portfela i jego optymalizacja na rynku kapitatowym, [w:] Zarzadzanie finansami, Zeszyty Naukowe, Wydawnictwo Uniwersytetu Szczecińskiego.

Tymiński J., Zawiślak R., 2009, Wykorzystanie elementów teorii sterowania $w$ problematyce optymalizacji portfela inwestycyjnego na rynku kapitałowym, [w:] Zarzqdzanie finansami, Zeszyty Naukowe, Wydawnictwo Uniwersytetu Szczecińskiego.

\section{Jerzy Tymiński}

\section{ELEMENTY TEORII STEROWANIA ZASTOSOWANE DO PORTFELA INWESTYCYJNEGO NA RYNKU KAPITAŁOWYM. OPTYMALNY MOMENT SPRZEDAŻY PORTFELA}

$\mathrm{W}$ artykule przedstawiono koncepcję sterowania kapitałem $\mathrm{w}$ procesach nabycia portfeli inwestycyjnych. Nabywany portfel został zoptymalizowany według dwóch wariantów. Portfel I wyliczony został przy zastosowaniu metody tradycyjnej. Portfel II skonstruowany został z wykorzystaniem elementów teorii niezawodności i metody programowania dynamicznego. Artykuł zawiera również analizę odsprzedaży posiadanego portfela $\mathrm{w}$ aspekcie popytu na instrumenty finansowe na rynku kapitałowym oraz wyznaczenie najkorzystniejszego dla inwestora momentu tej transakcji. Przedstawiona koncepcja dotycząca racjonalnych decyzji inwestycyjnych w transakcjach na Giełdzie Papierów Wartościowych w Warszawie może być stosowana przez menedżerów przy określaniu efektywnego portfela instrumentów finansowych.

Słowa kluczowe: sterowanie, optymalny moment, sprzedaż portfela. 


\section{ANNEXE}

Table 1. Prices of stocks of selected companies listed at WSE

\begin{tabular}{|l|r|r|r|r|r|r|r|r|r|r|r|}
\hline \multicolumn{10}{|c|}{ Price (PLN) } \\
\hline & $\begin{array}{c}1 \text { June } \\
2005\end{array}$ & $\begin{aligned} 1 \text { July } \\
2005\end{aligned}$ & $\begin{array}{c}1 \text { Aug. } \\
2005\end{array}$ & $\begin{array}{c}1 \text { Sept. } \\
2005\end{array}$ & $\begin{array}{c}1 \text { Oct. } \\
2005\end{array}$ & $\begin{array}{c}1 \text { Nov. } \\
2005\end{array}$ & $\begin{array}{c}1 \text { Dec. } \\
2005\end{array}$ & $\begin{array}{c}1 \text { Jan. } \\
2006\end{array}$ & $\begin{array}{c}1 \text { Feb. } \\
2006\end{array}$ & $\begin{array}{c}\text { 1 March } \\
2006\end{array}$ & $\begin{array}{c}\text { 1 April } \\
2006\end{array}$ \\
\hline \hline APL & 3.12 & 3.10 & 3.00 & 2.96 & 2.89 & 2.63 & 3.52 & 4.02 & 4.42 & 6.60 & 6.15 \\
\hline BDX & 45.50 & 46.90 & 43.00 & 43.30 & 40.00 & 40.00 & 36.00 & 38.00 & 45.00 & 45.00 & 46.80 \\
\hline GRJ & 22.40 & 21.85 & 22.30 & 21.30 & 26.40 & 27.50 & 34.70 & 35.10 & 37.00 & 35.70 & 38.00 \\
\hline GTC & 114.30 & 112.00 & 122.00 & 135.00 & 144.00 & 136.00 & 145.00 & 172.00 & 203.00 & 260.50 & 286.00 \\
\hline INT & 10.21 & 9.70 & 11.70 & 11.65 & 11.15 & 9.90 & 18.10 & 18.90 & 27.90 & 28.00 & 30.20 \\
\hline JTZ & 69.50 & 70.00 & 74.20 & 79.00 & 81.90 & 74.90 & 75.00 & 86.50 & 77.00 & 29.10 & 73.80 \\
\hline KRS & 11.20 & 12.00 & 10.50 & 8.45 & 8.90 & 8.00 & 7.60 & 7.95 & 8.00 & 7.00 & 7.25 \\
\hline PEO & 141.90 & 143.50 & 150.50 & 163.50 & 181.50 & 157.00 & 176.00 & 174.50 & 173.30 & 188.50 & 190.50 \\
\hline PKM & 100.35 & 99.00 & 111.50 & 116.00 & 116.00 & 123.00 & 127.50 & 136.50 & 140.00 & 149.00 & 147.50 \\
\hline RPC & 16.90 & 18.55 & 20.80 & 20.30 & 20.20 & 21.00 & 20.80 & 24.40 & 25.50 & 26.00 & 27.50 \\
\hline SKA & 25.65 & 27.30 & 24.60 & 24.50 & 22.30 & 23.30 & 25.20 & 26.60 & 28.00 & 27.60 & 29.80 \\
\hline WWL & 118.75 & 119.50 & 120.00 & 122.50 & 139.00 & 136.00 & 150.00 & 168.00 & 171.00 & 232.00 & 234.00 \\
\hline WIG & 29539.21 & 28308.71 & 30408.01 & 31479.57 & 33898.06 & 31937.43 & 34012.14 & 35466.39 & 37423.17 & 3902590 & 40199.06 \\
\hline
\end{tabular}

Source: developed by the author based on data derived from the „PARKIET” periodical.

Table 2. Rates of return on for 10-month periods

\begin{tabular}{|l|r|r|r|r|r|r|c|c|c|c|c|}
\hline \multicolumn{10}{|c|}{ Monthly rates of return on stocks (from 1 June 2005 to 1 March 2006; \%) } \\
\hline & $\begin{array}{c}\text { Rate of } \\
\text { return } r_{1}\end{array}$ & $\begin{array}{c}\text { Rate of } \\
\text { return } r_{2}\end{array}$ & $\begin{array}{c}\text { Rate of } \\
\text { return } r_{3}\end{array}$ & $\begin{array}{c}\text { Rate of } \\
\text { return } r_{4}\end{array}$ & $\begin{array}{c}\text { Rate of } \\
\text { return } r_{5}\end{array}$ & $\begin{array}{c}\text { Rate of } \\
\text { return } r_{6}\end{array}$ & $\begin{array}{c}\text { Rate of } \\
\text { return } r_{7}\end{array}$ & $\begin{array}{c}\text { Rate of } \\
\text { return } r_{8}\end{array}$ & $\begin{array}{c}\text { Rate of } \\
\text { return } r_{9}\end{array}$ & $\begin{array}{c}\text { Rate of } \\
\text { return } r_{10}\end{array}$ & $\begin{array}{c}\text { Expected } \\
\text { rate of } \\
\text { return } r_{i}\end{array}$ \\
\hline \hline APL & -0.64 & -3.23 & -1.33 & -2.36 & -9.00 & 33.84 & 14.20 & 9.95 & 49.32 & -6.82 & 8.39 \\
\hline BDX & 3.08 & -8.32 & 0.70 & -7.62 & 0.00 & -10.00 & 5.56 & 18.42 & 0.00 & 4.00 & 0.58 \\
\hline GRJ & -2.46 & 2.06 & -4.48 & 23.94 & 4.17 & 26.18 & 1.15 & 5.41 & -3.51 & 6.44 & 5.89 \\
\hline GTC & -2.01 & 18.75 & 1.50 & 6.67 & -5.56 & 6.62 & 18.62 & 18.02 & 28.33 & 9.79 & 10.07 \\
\hline INT & -5.00 & 20.62 & -0.43 & -4.29 & -11.21 & 82.83 & 4.42 & 47.62 & 0.36 & 7.86 & 14.28 \\
\hline JTZ & 0.72 & 6.00 & 6.47 & 3.67 & -8.55 & 0.13 & 15.33 & -10.98 & -10.26 & 6.80 & 0.93 \\
\hline KRS & 7.14 & -12.50 & -19.52 & 5.33 & -10.11 & -5.00 & 4.61 & 0.63 & -12.50 & 3.57 & -3.84 \\
\hline PEO & 1.13 & 4.88 & 8.64 & 11.01 & -13.50 & 12.10 & -0.85 & -0.69 & 8.77 & 1.06 & 3.25 \\
\hline PKM & -1.35 & 12.63 & 4.04 & 0.00 & 6.03 & 3.66 & 7.06 & 2.56 & 6.43 & -1.01 & 4.01 \\
\hline RPC & 9.76 & 12.13 & -2.40 & -0.49 & 3.96 & -0.95 & 17.31 & 4.51 & 1.96 & 5.77 & 5.16 \\
\hline SKA & 6.43 & -9.89 & -0.41 & -8.98 & 4.48 & 8.15 & 5.56 & 5.26 & -1.43 & 7.97 & 1.72 \\
\hline WWL & 0.63 & 0.42 & 2.08 & 12.47 & -2.16 & 10.29 & 12.00 & 1.79 & 35.67 & 0.86 & 7.51 \\
\hline WIG & -4.17 & 7.42 & 3.52 & 7.68 & -5.78 & 6.50 & 4.28 & 5.52 & 4.28 & 3.01 & 3.23 \\
\hline
\end{tabular}

Source: developed by the author based on data derived from the „PARKIET” periodical. 